\section{PENELITIAN PENGARUH SUDUT KEMIRINGAN RAK PADA \\ UJI OUT DOOR TERHADAP SIFAT TEGANGAN PUTUS, PERPANJANGAN PUTUS SOL KARET CETAK. Oleh : Suprapto \\ ABSTRACT}

The aim of this research is to find out the effect of weathering exposure on the quality of moulding rubber which is influenced by the air directly. In this research, the samples of the experiment are installed on shelves which each of the shelves has an $0^{\circ}, 15^{\circ}, 30^{\circ}$, and $45^{\circ}$ angle.

The experiment samples taking which will be examined their physical properties will be taken every 40 days. The highest change of the speciments physical properties happened at the shelf which has the angle a $30^{\circ}$ angle.

\section{INTISARI}

Penelitian ini bertujuan untuk mengetahui pengaruh cuaca luar terhadap mutu sol karet cetak yang langsung dikenakan udara luar. Dalam melaksanakan penelitian ini contoh uji dipasang di atas rak yang sudut kemiringannya diatur masing-masing : $0^{\circ}, 15^{\circ}, 30^{\circ}$, dan $45^{\circ}$. Pengambilan contoh uji yang akan diuji sifat fisiknya, diambil setiap 40 hari sekali. Perubahan sifat fisika contoh uji terbesar terjadi pada rak dengan sudut kemiringan $30^{\circ}$

\section{PENDAHULUAN}

Sepatu kanvas dengan sol karet cetak merupakan bagian dari sepatu, pada umumnya dalam penggunaannya langsung terkena oleh cuaca baik oleh sinar matahari maupun hujan. Sehingga dapat menyebabkan terjadinya perubahan sifat-sifat fisis dari sol karet cetak tersebut. Untuk mengetahui sampai sejauh mana adanya perubahan sifat yang terjadi pada sol karet cetak, maka perlu diadakan suatu penelitian tentang pengaruh cuaca luar terhadap sifat-sifat fisika sol karet cetak. Indonesia terletak disekitar katulistiwa, maka iklimnya termasuk iklim tropis, pergantian udara selama waktu yang panjang antara 10 tahun hingga 30 tahun di suatu daerah. (5).

Banyaknya panas yang diterima oleh bumi dipengaruhi oleh :

1. Kedudukan matahari.

2. Lamanya penyinaran.

3. Macam tanah dan benda yang ada diantaranya.

Pengaruh cuaca terhadap barang karet diselidiki oleh beberapa ahli, antara lain :

Soele (3) membandingkan perubahan dari sifat mekanis terhadap $30 \mathrm{cam}-$ puran karet alam setelah satu tahun dilaksanakan aging alam, setelah 24 jam dan 48 jam dalam oxygen Bomb (pada kondisi suhu $60^{\circ} \mathrm{C}$ dengan tekanan 20 atmosfer), dan setelah 96 jam dalam geer oven pada suhu $70^{\circ} \mathrm{C}$

Menurut Crab Tree dan Cramb (3), suatu oksidasi dipercepat oleh adanya cahaya, yang mana tidak tergantung pada tegangan dari karet melainkan ditentukan oleh indek penyebaran bahan pengisi (filler), sedangkan karetnya sendiri kurang berpengaruh.

Menurut Van Rossen dan Tallen (3) bahwa pengaruh cuaca terhadap bahan karet sebagai berikut :

1. Cahaya mempunyai peranan penting pada pembentukan cracking terutama pada yang langsung terkena penyinaran akan terjadi suatu oksidasi.

2. Ozon udara buatan dapat menghasilkan crack yang sama dengan udara luar, hanya besarnya ditentukan oleh kandungan dari masing-masing bahan seperti : $\mathrm{NO}_{2}, \mathrm{SO}_{2}$, dan $\mathrm{CI}$.

3. Bahan pelunak karet memberikan pengaruh terhadap pembentukan crack pada bagian tertentu, dimana bagian yang terkena sinar matahari akan teroksidasi nampak jelas dibandingkan dengan campuran kompon yang terkontrol, mineral karet ini menyebabkan menjadi lebih buruk sifat fisiknya.

Vol X NO. 18 Tahun 1993/1994 
Pengaruh pemberian bahan pelunak kedalam kompon karet terhadap pembentukan retak-retak, maka pada bagian yang kena sinar matahari pengaruh dari oksidasi terlihat sangat jelas.

\section{MATERI DAN METODE PENELITIAN.}

A. Materi Penelitian.

1. Bahan.

Bahan-bahan yang digunakan dalam penelitian ini berupa sol karet cetak yang langsung diperoleh dari perusahaan sepatu.

2. Alat-alat yang digunakan :

a. Pisau potong contoh uji sol karet cetak bentuk dayung memakai pisau potong Pons D.

b. Jangka sorong dan penggaris.

c. Alat uji out door.

d. Alat ukur tebal (mikrometer) dengan ketelitian 0,05 mm.

e. Alat uji kuat tarik dan mulur (Tensile Strength)

B. Metode Penelitian.

Untuk melaksanakan penelitian pengaruh cuaca terhadap mutu sol karet cetak, secara langsung dikenakan cuaca udara luar dilaksanakan dilokasi Balai Besar Penelitian Dan Pengembangan Industri Barang Kulit Dan Plastik yang terletak didaerah Yogyakarta. Secara geografis Kodya Yogyakarta terletak pada ketinggian 116,66 meter diatas permukaan air laut, dengan keadaan cuaca yang selalu berubah-ubah setiap bulannya. Sehubungan dengan hal tersebut maka dalam melaksanakan penelitian pengaruh cuaca diudara luar contoh uji diletakkan diatas rak yang mempunyai ukuran : panjang 1,5 meter, lebar 1 meter, tebal $3 \mathrm{~mm}$ dan pada bagian bawah diberi kaki penyangga yang terbuat dari besi dengan ketinggian 1,5 meter. Dengan adanya tiang penyangga ini, maka rak dapat diatur kemiringannya. Pemasangan alat tersebut menghadap arah equator. Alat yang dipergunakan dalam penelitian ini diatur sudut kemiringannya sebesar : $0^{\circ}, 15^{\circ}, 30^{\circ}$ dan $45^{\circ}$

Kemudian diatas rak ini diletakkan contoh uji yang akan diteliti. Pengaturan sudut kemiringan dimaksudkan untuk mengetahui pengaruh terbesar terhadap perubahan sifat-sifat fisis dari contoh yang akan diuji. Adapun sol karet cetak yang dipakai sebagai contoh uji diperoleh dari satu macam kompon yang diproses pada kondisi yang sama, sehingga didapatkan sol yang mempunyai mutu seragam. Alat uji out door ini ditem- patkan pada lokasi yang terbebas dari gangguan benda-benda yang dapat menghalangi datangnya sinar matahari pada permukaan bahan contoh uj yang akan diteliti. Contoh uji yang di perlakukan dengan alat ini selama 480 hari dengan pengambilan contoh uji dilaksanakan setiap 40 hari sekali. Selanjutnya diadakan pengujian-pengujian sifat fisisnya yang berupa tegangan putus dan perpanjangan putus, yang masng-masing dengan tiga kali ulangan. Data yang diperoleh dari hasil pengujian sifat-sifat fisisnya selanjutnya dianalisa dengan menggunakan metode $T$ test.

\section{Hasil Penelitian Dan Pembahasan}

Hasil uji fisis tegangan putus dan perpanjangan putus sol karet cetak dengan melalui tiga kali ulangan. Adapun data rata-rata dari tiga kali ulangan dapat dilihat pada tabel berikut ini :

Tabel 1. : Data rata-rata hasil uji tegangan putus sol karet cetak $\left(\mathrm{Kg} / \mathrm{Cm}^{2}\right)$.

\begin{tabular}{|c|c|c|c|c|c|}
\hline \multirow{2}{*}{$\begin{array}{l}\text { Variasi } \\
\text { waktu } \\
\text { (hari) }\end{array}$} & \multirow{2}{*}{$\begin{array}{c}\text { Tanpa } \\
\text { perlakuan } \\
\text { (Blangko) }\end{array}$} & \multicolumn{4}{|c|}{ Perlakuan sudut Kemiringan Rak } \\
\hline & & $0^{\circ}$ & $15^{\circ}$ & $30^{\circ}$ & $45^{\circ}$ \\
\hline 40 hari & 119,92 & 71,87 & 51,92 & 81,64 & 64,90 \\
\hline 80 hari & 119,92 & 64,96 & 59,84 & 73,52 & 71,39 \\
\hline 120 hari & 119,92 & 66,75 & 50,24 & 54,19 & 61,53 \\
\hline 160 hari & 119,92 & 50,65 & 47,36 & 46,67 & 52,17 \\
\hline 200 hari & 119,92 & 45,52 & 37,36 & 45,25 & 41,40 \\
\hline 240 hari & 119,92 & 44,59 & 34,16 & 28,24 & 38,21 \\
\hline 280 hari & 119,92 & 38,12 & 29,35 & 26,09 & 37,80 \\
\hline 320 hari & 119,92 & 28,27 & 25,01 & 23,08 & 35,00 \\
\hline \multirow{2}{*}{$\begin{array}{l}\text { Variasi } \\
\text { waktu } \\
\text { (hari) }\end{array}$} & \multirow{2}{*}{$\begin{array}{c}\text { Tanpa } \\
\text { perlakuan } \\
\text { (Blangko) }\end{array}$} & \multicolumn{4}{|c|}{ Perlakuan sudut Kemiringan Rak } \\
\hline & & $0^{\circ}$ & $15^{\circ}$ & $30^{\circ}$ & $45^{\circ}$ \\
\hline 360 hari & 119,92 & 28,27 & 24,26 & 22,34 & 29,07 \\
\hline 400 hari & 119,92 & 26,40 & 24,43 & 22,18 & 27,29 \\
\hline 440 hari & 119,92 & 23,13 & 23,93 & 22,10 & 26,91 \\
\hline 480 hari & 119,92 & 23,05 & 23,49 & 21,29 & 26,90 \\
\hline
\end{tabular}


Tabel 2:

Data rata-rata hasil uji perpanjangan putus sol sepatu karet cetak dalam \%

\begin{tabular}{c|r|r|r|r|r}
\multirow{2}{*}{$\begin{array}{c}\text { Variasi } \\
\text { waktu } \\
\text { (hari) }\end{array}$} & $\begin{array}{c}\text { Tanpa } \\
\text { perlakuan } \\
\text { (Blangko) }\end{array}$ & \multicolumn{3}{|c}{ Perlakuan sudut Kemiringan Rak } \\
\cline { 3 - 6 } & $0^{\circ}$ & \multicolumn{1}{|c}{$15^{\circ}$} & \multicolumn{1}{|c}{$30^{\circ}$} & \multicolumn{1}{c}{$45^{\circ}$} \\
\hline 40 hari & 233,80 & 199,97 & 139,83 & 129,63 & 223,70 \\
80 hari & 233,80 & 154,00 & 98,67 & 120,67 & 171,33 \\
120 hari & 233,80 & 147,67 & 110,67 & 115,33 & 156,00 \\
160 hari & 233,80 & 144,00 & 85,30 & 94,00 & 138,00 \\
200 hari & 233,80 & 100,00 & 80,00 & 68,33 & 107,00 \\
240 hari & 233,80 & 107,00 & 78,17 & 64,67 & 98,00 \\
280 hari & 233,80 & 101,33 & 71,00 & 64,00 & 88,00 \\
320 hari & 233,80 & 81,67 & 64,00 & 61,33 & 77,33 \\
360 hari & 233,80 & 79,00 & 56,67 & 59,00 & 73,33 \\
400 hari & 233,80 & 73,33 & 55,33 & 52,67 & 72,33 \\
440 hari & 233,80 & 72,67 & 53,33 & 52,67 & 71,33 \\
480 hari & 233,80 & 72,33 & 53,33 & 52,33 & 72,33 \\
\hline
\end{tabular}

Dari data hasil pengujian sifat fisis sol sepatu karet cetak tersebut diatas perhitungan perubahan sifat fisis oentoh uji setelah dikenakan perlakuan out door, dengan sudut kemiringan yang berbeda-beda, ternyata menunjukkan perubahan sifat yang tidak jauh berbeda antara rak yang satu dengan lainnya. Dengan demikian setiap sudut kemiringan rak memberikan pengaruh yang sama terhadap cuplikkan yang diuji.

Untuk mengetahui apakah diantara perlakuan yang dikenakan pada cuplikan sol sepatu karet cetak yang diuji berbeda nyata, atau tidak, maka data hasil uji sifat fisis yang diperoleh lebih lanjut dianalisa secara statistik dengan metoda $\mathrm{T}$ test yang memberi hasil sebagai berikut :

Pada uji tegangan putus dari cuplikan sol karet cetak yang dikenakan perlakuan cuaca terhadap sinar matahari dan hujan (out door) dengan sudut kemiringan antara $0^{\circ}$ dan $15^{\circ}$, selama 480 hari ternyata menunjukkan perhitungan t hitung 3,64 > dari t tabel 2,20.

Jadi sifat tegangan putus pada sudut kemiringan antara $0^{\circ}$ dan $15^{\circ}$, perbedaan nyata.
Demikian juga halnya sifat fisis yang berupa perpanjangan putus pada sudut kemiringan antara $0^{\circ}$ dan $15^{\circ}$ menunjukkan perhitungan $t$ hitung $6,699>t$ tabel 2,201. Jadi sifat perpanjangan putus pada sudut kemiringan antara $0^{\circ}$ dan $15^{\circ}$ perbedaan nyata.

Untuk cuplikkan sol karet cetak yang diperlakukan pada waktu yang sama yaitu 480 hari terhadap sinar matahari dan hujan (out door) dengan sudut kemiringan antara $0^{\circ}$ dan $30^{\circ}$ ternyata menunjukkan perhitungan $t$ hitung $1,682<\mathrm{t}$ tabel 2,201. Jadi sifat tegangan putus pada sudut kemiringan antara $0^{\circ}$ dan $30^{\circ}$ perbedaan tidak nyata.

Demikian juga halnya dengan sifat fisis yang berupa perpanjangan putus pada sudut kemiringan antara $0^{\circ}$ dan $30^{\circ}$ menunjukkan perhitungan t hitung $7,464>t$ tabel 2,201. Jadi sifat perpanjangan putus pada sudut kemiringan antara $0^{\circ}$ dan $30^{\circ}$ perbedaan nyata.

Untuk cuplikan sol sepatu karet cetak yang diperlukan pada waktu sama yaitu selama 480 hari terhadap sianr matahari dan hujan (out door) dengan sudut kemiringan antara $15^{\circ}$ dan $45^{\circ}$ ternyata menunjukkan perhitungan t hitung $-6,177<t$ tabel 2,201 . Jadi sifat tegangan putus pada sudut kemiringan antara $15^{\circ}-45^{\circ}$ perbedaan tidak nyata. Demikian juga halnya sifat-sifat fisis yang berupa perpanjangan putus pada sudut kemiringan antara $15^{\circ}-45^{\circ}$ menunjukkan perhitungan $t$ hitung-4,780 $<\mathrm{t}$ tabel 2,201. Jadi sifat perpanjangan putus pada sudut kemiringan $15^{\circ}-45^{\circ}$ perbedaan tidak nyata terhadap blangkonya.

Untuk cuplikan sol sepatu karet cetak yang diperlukan pada waktu yang sama yaitu selama 480 hari terhadap sinar matahari dan hujan (out door) dengan sudut kemiringan antara $15^{\circ}-30^{\circ}$ ternyata menunjukkan perhitungan t hitung $0,3873<t$ tabel 2,201. Jadi sifat tegangan putus pada sudut kemiringan antara $15^{\circ}-30^{\circ}$ perbedaan tidak nyata. Demikian juga sifat fisis yang berupa perpanjangan putus pada sudut kemiringan antara $15^{\circ}-30^{\circ}$ ternyata menunjukkan perhitungan $\mathrm{t}$ hitung $0,343<\mathrm{t}$ tabel 2,201. Jadi sifat perpanjangan putus pada sudut kemiringan antara $15^{\circ}-30^{\circ}$ perbedaan tidak nyata.

Untuk cuplikan sol sepatu karet cetak yang diperlukan pada waktu yang sama yaitu selama 480 hari terhadap sinar matahari dan hujan (out door) dengan sudut kemiringan antara $30^{\circ}-45^{\circ}$, ternyata menunjukkan perhitungan t hitung $-1,6152<\mathrm{t}$ tabel 2,201 . Jadi sifat tegangan putus pada sudut kemiringan antara $30^{\circ}-45^{\circ}$ perbedaan tidak nyata. Demikian juga sifat fisis yang berupa perpanjangan putus pada sudut kemiringan antara $30^{\circ}-45^{\circ}$, ternyata menunjukkan perhitungan $t$ hitung $\mid-5,347<$ t tabel 2,201 . Jadi sifat perpanjangan putus pada sudut kemiringan antara $30^{\circ}-45^{\circ}$ perbedaan tidak nyata.

Vol IX No. 18 Tahun 1993/1994 
Untuk cuplikan sol sepatu karet cetak yang diperlakukan pada waktu yang sama yaitu selama 480 hari terhadap sinar matahari dan hujan (out door) dengan sudut kemiringan antara $45^{\circ}-0^{\circ}$ ternyata menunjukkan perhitungan $\mathrm{t}$ hitung $0,027<\mathrm{t}$ tabel 2,201. Jadi sifat tegangan putus pada sudut kemiringan antara $45^{\circ}-0^{\circ}$ perbedaan tidak nyata. Demikian juga sifat fisis yang berupa perpanjangan putus pada sudut kemiringan antara $45^{\circ}-0^{\circ}$ ternyata menunjukkan perhitungan $t$ hitung $0,416<\mathrm{t}$ tabel 2,201 . Jadi sifat perpanjangan putus pada sudut kemiringan antara $45^{\circ}-0^{\circ}$ perbedaan tidak nyata.

Berdasarkan pada uraian tersebut diatas dapat diketahui bahwa pada uji tegangan putus dari enam perlakuan sekali diantaranya menunjukkan perbedaan dengna blangkonya. Sedangkan untuk uji perpanjangan putus dari enam macam perlakuan dua diantaranya ada perbedaan dengan blangkonya.

\section{KESIMPULAN}

1. Dari hasil analisa statistik sifat tegangan putus dan perpanjangan putus ada yang berbeda nyata serta ada pula yang tidak berbeda nyata.

2. Perbedaan sifat fisis cuplikan setelah dikenakan perlakuan out door, dengan sudut kemiringan yang berbeda-beda ternyata menunjukkan perubahan sifat yang tidak jauh berbeda antara rak yang satu dengan rak yang lainnya.

3. Penelitian terhadap sol sepatu karet cetak yang langsung dikenakan pengaruh cuaca udara luar dengan sudut kemiringan antara $0^{\circ}-45^{\circ}$, ternyata rak dengan sudut kemiringan $30^{\circ}$ memberikan perubahan sifat tegangan putus paling besar.

\section{DAFTAR PUSTAKA}

1. David Sinas, Weathering of polymer aplied science publishere 19.

2. Gouri K. John, Wiley, Statistical consepts and Methode, New York 1977.

3. Kluckous Paul Dr. Ing, Rubber and plastik, London Chamanan and Hall 1965.

4. Winer Bj. statistical Prinsiples in Experimental Design, Secon Edition, MC. Grow - Hill Kegakusha, 1971.

5. Suidjiran Resosudarmo Prof. Dr. MA, Ilmu Bumi Alam PT Rosda (Rj) Jayapura.
Lampiran :

Rekapitulasi hasil Analisa Statistik Tegangan Putus dengan metode T Test selama 480 hari.

\begin{tabular}{l|r|r|r|r|r}
\hline \multirow{2}{*}{ Komponen } & \multicolumn{5}{|c}{ Sudut Kerniringan } \\
\cline { 2 - 6 } & $0^{\circ}$ dan $15^{\circ}$ & $0^{\circ}$ dan $30^{\circ}$ & $15^{\circ}$ dan $45^{\circ}$ & $30^{\circ}$ dan $45^{\circ}$ & $45^{\circ}$ dan $0^{\circ}$ \\
\hline $\mathrm{Cf}$ & 543,65 & 172,748 & 549,724 & 176,180 & $0,0,0168$ \\
$\mathrm{Cs}$ & 451,49 & 671,6535 & 158,51 & 712,157 & 246,108 \\
$\mathrm{Ms}$ & 41,04 & 61,059 & 14,41 & 67,688 & 22,373 \\
$\mathrm{Sd}$ & 6,41 & 7,814 & 3,796 & 8,213 & 4,730 \\
$\mathrm{SED}$ & 1,85 & 2,255 & 1,095 & 2,371 & 1,365 \\
$\mathrm{t}$ Hitung & 3,64 & 1,682 & $-6,177$ & $-1,615$ & 0,027 \\
t Tabel & 2,201 & 2,201 & 2,201 & 2,201 & 2,201 \\
& Perbedaan & Perbedaan & Perbedaan & Perbedaan & Perbedaan \\
& nyata & Tidak & Tidak & Tidak & Tidak \\
& & nyata & nyata & Nyata & nyata. \\
\hline
\end{tabular}

Rekapitulasi hasil Analisa Statistik perpanjangan putus dengan metode T test selama 480 hari.

\begin{tabular}{l|r|r|r|r|r}
\hline \multirow{2}{*}{ Komponen } & \multicolumn{5}{|c}{ Sudut Kemiringan } \\
\cline { 2 - 6 } & $0^{\circ}$ dan $15^{\circ}$ & $0^{\circ}$ dan $30^{\circ}$ & $15^{\circ}$ dan $45^{\circ}$ & $30^{\circ}$ dan $45^{\circ}$ & $45^{\circ}$ dan $0^{\circ}$ \\
\hline Cf & $12.459,473$ & $13.222,895$ & $13.492,471$ & $14,286,45$ & 20,567 \\
Cs & $3.054,412$ & $2.610,575$ & $6.493,79$ & $5.497,51$ & 1309,73 \\
Ms & 277,674 & 237,325 & 590,340 & 499,774 & 119,066 \\
Sd & 16,663 & 15,405 & 24,296 & 22,355 & 10,911 \\
SED & 4,810 & 4,447 & 7,013 & 6,453 & 3,149 \\
t Hitung & 6,699 & 7,464 & $-4,780$ & $-5,34$ & 0,416 \\
t Tabel & 2,201 & 2,201 & 2,201 & 2,201 & 2,201 \\
Perbedaan & Perbedaan & Perbedaan & Perbedaan & Perbedaan & Perbedaan \\
Nyata & Nyata & Tidak & tidak & tidak & tidak \\
& & Nyata & nyata & nyata & nyata. \\
\hline
\end{tabular}

Vol IX No. 18 Tahun 1993/1994 